\title{
Pollen morphology of selected species of the subfamily Bombacoideae (Malvaceae sensu lato) ${ }^{1}$
}

\author{
Vanessa Holanda Righetti de Abreu², Claudia Barbieri Ferreira Mendonça² and Vania Gonçalves-Esteves ${ }^{2,3}$
}

Received: 21 December, 2013. Accepted: 28 January, 2014

\begin{abstract}
We analyzed the pollen grains of 11 species within the subfamily Bombacoideae. The pollen grains were acetolyzed, after which they were analyzed and photographed under light microscopy. Unacetolyzed pollen grains were analyzed and photomicrographed under scanning electron microscopy. We studied pollen characters such as shape, size, exine ornamentation and aperture type. The species were separated by a pollen key, which considers the presence or absence of "calotte" in the pollen grains. This attribute separated Ceiba and Eriotheca from the other genera. Some species are differentiated by specific characters: in Bombacopsis glabra and B. stenopetala, the sexine is rugulate or "vermiculate" with isolated pilate elements; in B. calophylla, the pollen grains are sinu-aperturate; Ceiba speciosa show atypical, duplicolumellate sexine; C. erianthos is the only species with 5-colporate pollen grains and a pentagonal amb; in Pachira aquatica the reticulum has muri with spiculaspinulose muri ("reticulum cristate"). The variation in the pollen morphology confirms the eurypalynous status of the genera studied here.
\end{abstract}

Key words: Atlantic Forest, Bombacoideae, palynology, Rio de Janeiro

\section{Introduction}

The order Malvales comprises approximately 10 families, 338 genera and 6005 species, with distribution primarily in tropical regions (APG II 2003).

Phylogenetic studies on Malvaceae sensu lato (Bayer et al. 1999) have identified nine clades, corresponding to the following subfamilies: Bombacoideae, Brownlowioideae, Byttnerioideae, Dombeyoideae, Grewioideae, Helicteroideae, Malvoideae, Sterculioideae, and Tilioideae. The subfamily Bombacoideae is pantropical and is generally represented by large, unbranched or aculeate trees, some with ventricose trunks in the middle portion, due to storage of water in the parenchyma (Duarte 2006).

The importance of palynology in the taxonomic classification of families and subfamilies has been demonstrated in various studies that used pollen data to reassess the groups; the study conducted by Saba (2007) is the one that best covers the species of Brazil, in terms of numbers and details. Similar studies include those conducted by Robyns (1963), Tsukada (1964), Palacios-Chávez (1966), Robyns (1971), Robyns \& Nilsson $(1975,1981)$, Nilsson \& Robyns (1974, 1986), Perveen et al. (2004), and Perveen \& Qaiser (2007).

Due to the taxonomic importance of the Malvaceae family and the need for studies to corroborate the circum- scription of the group, which remains uncertain, this study aimed to characterize the pollen morphology of the Bombacoideae species occurring in the state of Rio de Janeiro, which are distributed predominantly in areas of restinga (coastal woodland) and Atlantic Forest, in order to support taxonomic studies of the group.

\section{Material and methods}

The botanical material was taken from specimens deposited in herbaria: GUA, HB, R, RB and RBR; which acronyms are in accordance with the Index Herbariorum (Thiers continuously updated).

We collected buds or flowers from 11 species of the subfamily Bombacoideae: Bombacopsis calophylla (K. Schum.) A. Robyns; B. glabra (Pasq.) Robyns; B. stenopetala A. Robyns; Ceiba crispiflora (Kunth) Ravenna; C. erianthos (Cav.) K. Schum.; C. speciosa A. St.-Hil.; Eriotheca pentaphylla (Vell.) A. Robyns; Pachira aquatica Aubl.; Pseudobombax grandiflorum (Cav.) A. Robyns; Pseudobombax marginatum (A. St.-Hil., Juss. \& Cambess.) A. Robyns; and Spirotheca rivieri (Decne.) Ulbr. The slides used in the study were deposited in the Palynology Collection of the Álvaro Xavier Moreira Laboratory of Palynology, in the Botany Depart-

\footnotetext{
${ }^{1}$ Based on the Master's dissertation of the first author

${ }^{2}$ Universidade Federal do Rio de Janeiro, Museu Nacional, Departamento de Botânica, Laboratório de Palinologia, Rio de Janeiro, RJ, Brasil

${ }^{3}$ Author for correspondence: esteves.vr@gmail.com
} 
ment of the National Museum of the Federal University of Rio de Janeiro.

The pollen samples to be analyzed under light microscopy were treated with acetolysis (Erdtman 1960), as modified by Melhem et al. (2003), and measured within seven days of preparation (Salgado-Labouriau 1973). The images were captured with a Zeiss Axiostar Plus microscope (Carl Zeiss, Oberkochen, Germany). Pollen grains of each species $(n=25)$ were measured in equatorial view (polar diameter and equatorial diameter). The means, standard deviations of the mean, and $95 \%$ confidence intervals were calculated. Ten similar measurements of pollen grains were obtained from additional material - from another collection (hereafter referred to as comparison material) - to verify the stability of the data obtained from the reference material (Aguiar et al. 2008; Abreu et al. 2012; Moreira et al. 2013). Pollen grains ( $n=10 /$ species) were also measured in polar view (equatorial diameter in polar view and apocolpium side). Exine thickness and apertures ( $n=10 /$ species) were measured, and the arithmetic means were calculated. In describing the pollen characters, we used the terminology established by Punt et al. (2007), except for the polar area index and the size of the apertures, for which we used the classification system established by Faegri \& Iversen (1966).

Unacetolyzed pollen grains were mounted on stubs with double-sided carbon tape and sputter-coated (for $3 \mathrm{~min}$ ) with a thin layer of palladium-gold. The photomicrographs were taken under scanning electron microscopy with either a JSM-5310 microscope (JEOL, Ltd., Tokyo, Japan), in the Hertha Meyer Laboratory of Cellular Ultrastructure at the Federal University of Rio de Janeiro Institute of Biophysics, or a JSM-6390LV (JEOL, Ltd.) at the Electron Microscopy Center of the Department of Invertebrates of the National Museum of the Federal University of Rio de Janeiro.

\section{Results}

1. Bombacopsis calophylla (Fig. 1A-D), B. glabra (Fig. 1E-H), and B. stenopetala (Fig. 1I-L):

Pollen grains large, isopolar, peroblate (B. calophylla), oblate (B. glabra) and suboblate (B. stenopetala); with small or large polar area (Tab. 1 and 2), triangular amb, sinu-aperturate (B. calophylla only) or planaperturate, 3-colporate, long or short colpi in B. stenopetala, narrow colpi with prominent and ornamented margin, lolongate endoaperture (Tab. 3), wide mesocolpium, with large and "calotte"-shaped vertices with truncated contours only in B. calophylla (Fig. 1A and 1B) or smaller and rounded in the two other species (Fig. 1E, 1F, and 1I); in B. calophylla, the sexine is rugulate in the apocolpium (Fig. 1B, D) and microreticulate to rugulate near the apertures (Fig. 1C), muri with sparse perforations in the mesocolpium (Fig. 1B); in B. glabra and B. stenopetala, the sexine is "vermiculate" with isolated pilate elements, scabrate on the "calotte" (Fig. $1 \mathrm{E}, 1 \mathrm{G}, \mathrm{I})$, the distribution of the ornamentation elements being densest in B. stenopetala; sexine thicker than nexine. The pollen grain falls preferably in polar view, making it difficult to establish the shape and to measure the aperture.

2. Ceiba crispiflora (Fig. 2A-D), C. erianthos (Fig. 2E-H), and C. speciosa (Fig. 2I-L)

Pollen grains large, isopolar, suboblate, with a polar area that is small in C. erianthos, large in C. crispiflora, and large to very large in C. speciosa; subcircular or pentagonal amb in C. erianthos, 3-colporate with small colpi in C. crispiflora (Fig. 2C), 3(-4)-colporate with colpi ranging from short to very small in C. speciosa, (Fig. 2I and 2J), 5-colporate with long colpi in C. erianthos (Fig. 2G); narrow colpi with ornamented margin, not prominent, lolongate endoaperture

Table 1. Measurements of pollen grains of species within the subfamily Bombacoideae occurring in areas of restinga (coastal woodland) and Atlantic Forest in the state of Rio de Janeiro ( $\mathrm{n}=25$ grains/species, in equatorial view).

\begin{tabular}{|c|c|c|c|c|c|c|c|c|}
\hline \multirow{3}{*}{ Species } & \multicolumn{3}{|c|}{ Polar diameter } & \multicolumn{3}{|c|}{ Equatorial diameter } & \multirow{3}{*}{$\mathrm{PD} / \mathrm{ED}$} & \multirow{3}{*}{ Shape } \\
\hline & \multicolumn{3}{|c|}{$(\mu \mathrm{m})$} & \multicolumn{3}{|c|}{$(\mu \mathrm{m})$} & & \\
\hline & Variation & $\overline{\mathrm{x}} \pm \mathrm{s}_{\overline{\mathrm{x}}}$ & $95 \% \mathrm{CI}$ & Variation & $\overline{\mathrm{x}} \pm \mathrm{s}_{\overline{\mathrm{x}}}$ & $95 \% \mathrm{CI}$ & & \\
\hline Bombacopsis calophylla & $25.0-26.0$ & $25.5 \pm 0.1$ & $25.3-25.7$ & $70.0-72.0$ & $71.0 \pm 0.2$ & 70.6-71.4 & 0.36 & peroblate \\
\hline B. glabra & $47.5-57.5$ & $53.0 \pm 0.5$ & $52.0-54.0$ & $62.5-77.5$ & $71.2 \pm 0.9$ & $69.4-73.0$ & 0.74 & oblate \\
\hline B. stenopetala & $55.0-57.5$ & $55.6 \pm 0.2$ & $55.2-56.0$ & $67.5-77.5$ & $71.0 \pm 0.8$ & $69.4-72.6$ & 0.78 & suboblate \\
\hline Ceiba crispiflora & $53.0-63.0$ & $58.1 \pm 0.6$ & $56.9-59.3$ & $56.0-72.0$ & $66.9 \pm 0.9$ & $65.1-68.7$ & 0.87 & suboblate \\
\hline C. erianthos & $40.0-52.5$ & $50.2 \pm 0.8$ & $48.6-51.8$ & $57.5-72.5$ & $66.4 \pm 0.9$ & $64.6-68.2$ & 0.76 & suboblate \\
\hline C. speciosa & $45.0-57.5$ & $51.4 \pm 0.6$ & $50.2-52.6$ & $60.0-67.5$ & $64.0 \pm 0.7$ & $62.6-65.4$ & 0.80 & suboblate \\
\hline Eriotheca pentaphylla & $35.0-38.0$ & $35.8 \pm 0.3$ & $35.2-36.4$ & $51.0-52.0$ & $51.3 \pm 0.1$ & $51.1-51.2$ & 0.69 & oblate \\
\hline Pachira aquatica & $37.5-47.5$ & $42.7 \pm 0.6$ & $41.5-43.9$ & $70.0-77.5$ & $72.1 \pm 0.4$ & $71.3-72.9$ & 0.59 & oblate \\
\hline Pseudobombax grandiflorum & $42.5-45.0$ & $44.5 \pm 0.2$ & $44.1-44.9$ & $82.5-95.0$ & $88.2 \pm 0.8$ & $86.6-89.8$ & 0.50 & oblate \\
\hline Pseudobombax marginatum & $55.0-62.5$ & $58.8 \pm 0.8$ & $57.2-60.4$ & $77.5-92.5$ & $85.0 \pm 1.5$ & $81.9-88.1$ & 0.70 & oblate \\
\hline Spirotheca rivieri & $36.0-43.0$ & $40.3 \pm 0.4$ & $39.5-41.1$ & $55.0-65.0$ & $60.6 \pm 0.5$ & $59.6-61.6$ & 0.66 & oblate \\
\hline
\end{tabular}

$\overline{\mathrm{x}} \pm \mathrm{s}_{\overline{\mathrm{x}}}-$ arithmetic mean \pm standard deviation; $95 \% \mathrm{CI}$ - 95\% confidence interval; PD/ED - polar:equatorial diameter ratio. 
Table 2. Measurements of pollen grains of species within the subfamily Bombacoideae occurring in areas of restinga (coastal woodland) and Atlantic Forest in the state of Rio de Janeiro ( $\mathrm{n}=10$ grains/species, in polar view).

\begin{tabular}{|c|c|c|c|c|c|c|}
\hline \multirow{3}{*}{ Species } & \multicolumn{2}{|c|}{ EDPV } & \multicolumn{2}{|c|}{ AS } & \multirow{3}{*}{ PAI } & \multirow{3}{*}{ Polar area size } \\
\hline & \multicolumn{2}{|c|}{$(\mu \mathrm{m})$} & \multicolumn{2}{|c|}{$(\mu \mathrm{m})$} & & \\
\hline & Range & $\overline{\mathrm{x}}$ & Range & $\overline{\mathrm{x}}$ & & \\
\hline Bombacopsis calophylla & $60.0-72.5$ & 65.5 & $25.0-32.5$ & 28.1 & 0.43 & small \\
\hline B. glabra & $62.5-72.5$ & 66.1 & $22.5-35.0$ & 28.3 & 0.43 & small \\
\hline B. stenopetala & $62.5-72.5$ & 65.3 & $27.5-40.0$ & 34.5 & 0.53 & large \\
\hline Ceiba crispiflora & $52.0-66.0$ & 58.4 & $27.0-34.0$ & 30.2 & 0.52 & large \\
\hline C. erianthos & $55.0-77.5$ & 65.3 & $20.0-30.0$ & 23.8 & 0.36 & small \\
\hline C. speciosa & $57.5-67.5$ & 63.7 & $50.0-60.0$ & 54.5 & 0.85 & very large \\
\hline Eriotheca pentaphylla & $47.5-55.0$ & 50.5 & $30.0-35.0$ & 31.7 & 0.62 & large \\
\hline Pachira aquatica & $65.0-75.0$ & 70.9 & $37.5-47.5$ & 42.5 & 0.60 & large \\
\hline Pseudobombax grandiflorum & $76.3-90.0$ & 84.1 & $32.5-52.5$ & 43.3 & 0.51 & large \\
\hline Pseudobombax marginatum & $70.0-85.0$ & 80.2 & $27.5-37.5$ & 33.2 & 0.41 & small \\
\hline Spirotheca rivieri & $50.0-62.5$ & 56.3 & $22.5-37.5$ & 29.5 & 0.52 & large \\
\hline
\end{tabular}

EDPV - equatorial diameter in polar view; AS - apocolpium side; $\overline{\mathbf{x}}$ - arithmetic mean; $95 \%$ CI - 95\% confidence interval; PAI - polar area index.

(Tab. 3), reticulate and heterobrochate sexine, high, narrow and sinuous muri (Fig. 2D, 2H, and 2L): simplicolumellate with no elevation at the lumina intersection in C. crispiflora (Fig. 2D), or with elevation at the intersection of lumina, with perforations in C. erianthos; apparent columellae, sometimes branched or bifurcate in C. erianthos; large lumina, with ornamentation in C. erianthos (Fig. $2 \mathrm{H}$ ) or without ornamentation in C. crispiflora (Fig. 2D) and C. speciosa (Fig. 2L). In C. speciosa, muri are duplicolumellate in some regions, one of the rows has shorter columellae forming the muri, although it does not reach the base of the columellae in the other row (Fig. 2L); sexine thicker than nexine (Tab. 3).

\section{Eriotheca pentaphylla (Fig. 2M-O)}

Pollen grains large, isopolar, oblate, with large polar area (Tab. 1 and 2), subtriangular amb, planaperturate, 3 -colporate, small and narrow colpi, with no prominent ornamented margin (Fig. 2N); lalongate endoaperture (Tab. 3 ), heterobrochate reticulate sexine, low and wide muri, with sparse perforations, non apparent columellae, without bifurcation, intensely granulated lumen (Fig. 2O); sexine thicker than nexine (Tab. 3).

\section{Pachira aquatica (Fig. 3A-C)}

Pollen grains large, isopolar, oblate, with a large polar area (Tab. 1 and 2), subtriangular amb, planaperturate, 3 -colporate, small and narrow colpi with psilate margin, lolongate endoaperture (Tab. 3). The mesocolpium is large and has a large "calotte" with rounded contours, psilate in the most distal region (Fig. 3A and 3B) with 1-3 rows of perforations in the region between the border of the "calotte" and the surface of the pollen grains, in the other surface regions, the sexine is reticulate, heterobrochate, with low, narrow spinulose muri ("reticulum cristatum" according to
Hesse et al. 2009), columellae are not apparent and without bifurcation, lumen without ornamentation (Fig. 3B); sexine thicker than nexine (Tab. 3).

5. Pseudobombax grandiflorum (Fig. 3A-C) and P. marginatum (Fig. 3D-G)

Pollen grains large, isopolar, oblate, with a polar area that is small in P. marginatum and large in P. grandiflorum (Tab. 1 and 2), subtriangular amb, planaperturate, 3-colporate, long and narrow colpi with ornamented margin which is not prominent in $P$. marginatum, or small and very wide colpi with psilate margin in P. grandiflorum (Tab. 3), lolongate endoaperture (Fig. 3F, Tab. 3); the mesocolpium is wide and has a small, rounded "calotte", psilate surface (Fig. 3D, E), in other regions of the surface, the sexine is reticulate heterobrochate, with smooth, low, wide, straight muri, with sparse perforations in P. grandiflorum (Fig. 3G) or many perforations in P. marginatum (Fig. 3I), with no apparent columellae; they have minor lumina around major lumina; lumina with ornamentation (Fig. 3D, E, G); sexine thicker than nexine (Tab. 3).

\section{Spirotheca rivieri (Fig. 3J-L)}

Pollen grains large, isopolar, oblate, with a large polar area (Tab. 1 and 2), subtriangular amb, planaperturate, 3 -colporate, short and narrow colpi with highly ornamented and prominent margins, lolongate endoaperture (Tab. 3); the mesocolpium shows a smaller "calotte" with rounded contours, with a sexine that is psilate only in the most distal region, becoming microreticulate in the basal part of the "calotte" (Fig. 3J), in the apocolpium and near the apertures, the sexine is reticulate and heterobrochate, with high, narrow and straight muri with sparse perforations, apparent columellae without bifurcation, lumina without ornamentation (Fig. 3K, L); sexine thicker than nexine (Tab. 3). 

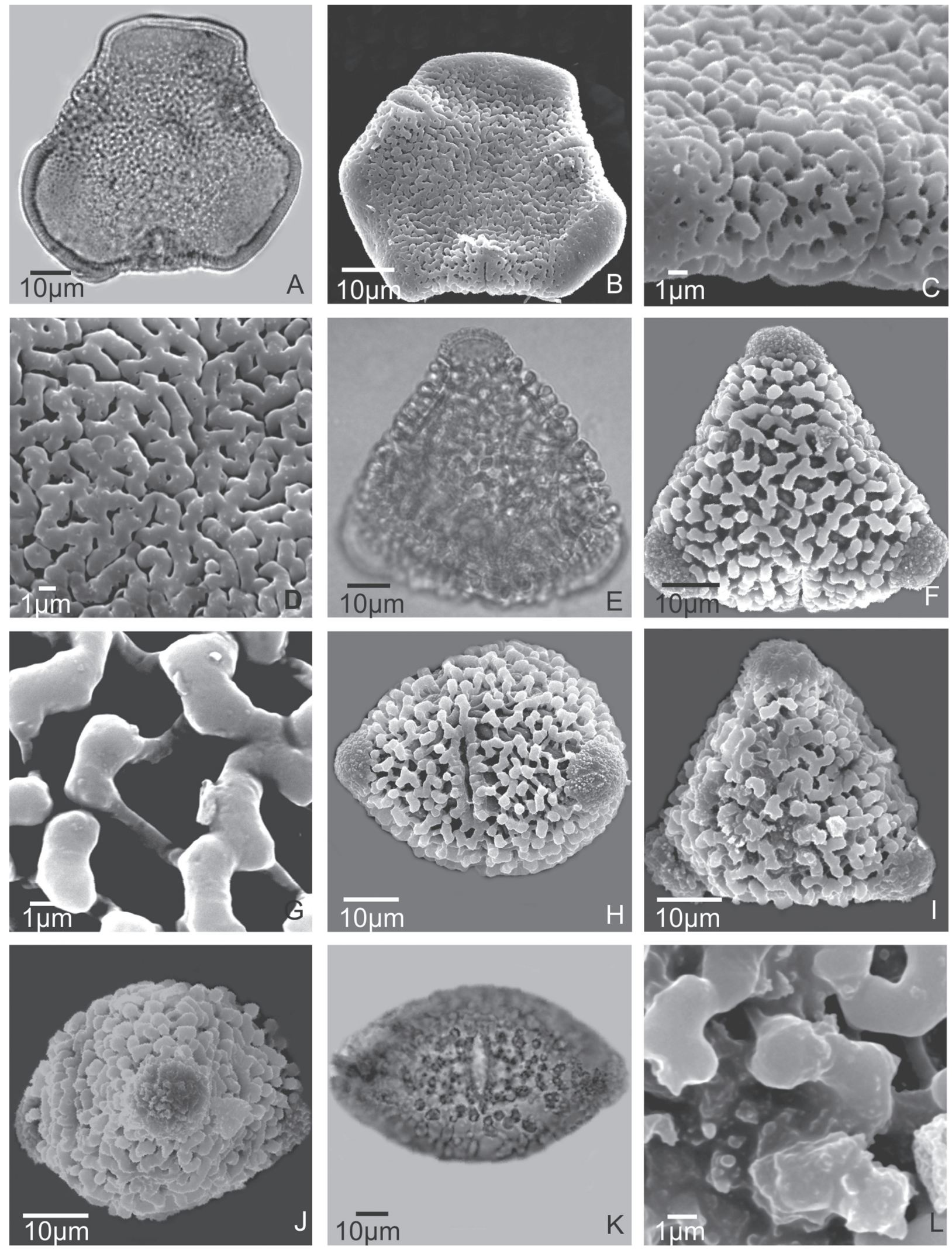

Figure 1. Pollen grains of species within the subfamily Bombacoideae (genus Bombacopsis) occurring in areas of restinga (coastal woodland) and Atlantic Forest in the state of Rio de Janeiro, under light microscopy (LM) and scanning electron microscopy (SEM): B. calophylla in polar view-A. optical section (LM) and B. general aspect (SEM); B. calophylla in equatorial view-C. aperture detail (SEM) and D. aperture detail (SEM); B. glabra in polar view -E. optical section (LM), F general aspect (SEM), and G. ornamentation detail (SEM); B. glabra in equatorial view-H. aperture (SEM); B. stenopetala in polar view-I. general aspect (SEM); B. stenopetala in equatorial view-J. general aspect (SEM), K. aperture (LM), and L. ornamentation detail (SEM). 

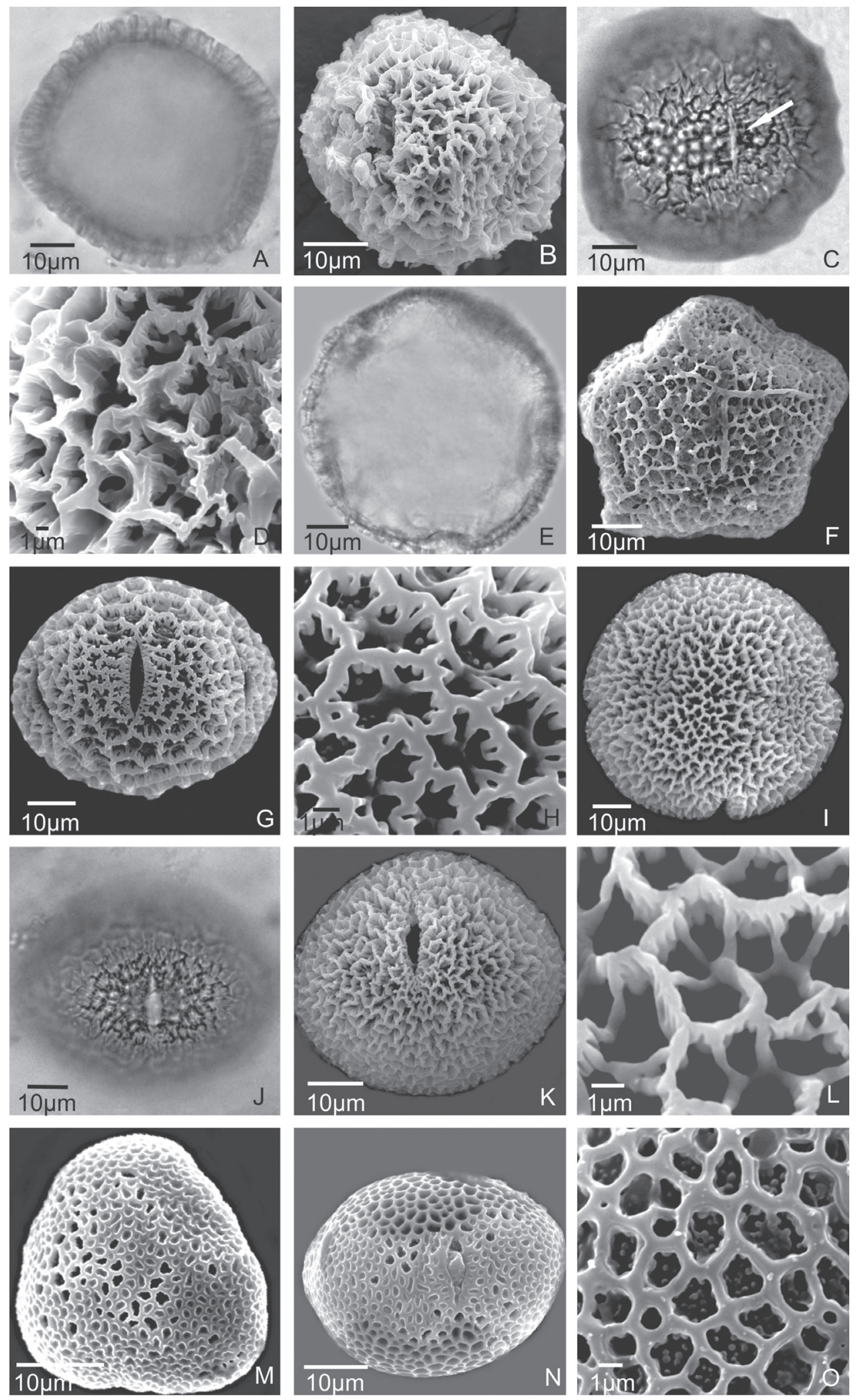

Figure 2. Pollen grains of species within the subfamily Bombacoideae (genera Ceiba and Eriotheca) occurring in areas of restinga (coastal woodland) and Atlantic Forest in the state of Rio de Janeiro, under light microscopy (LM) and scanning electron microscopy (SEM): C. crispiflora in polar view-A. optical section (LM) and B. general aspect (SEM); C. crispiflora in equatorial view-C. aperture (LM) and D. ornamentation detail (SEM); C. erianthos in polar view-E. optical section (LM) and F. general aspect (SEM); C. erianthos in equatorial view-G. aperture (SEM) and H. ornamentation detail (SEM); C. speciosa in polar view-I. general aspect (SEM); C. speciosa in equatorial view-J. aperture (LM), K. aperture (SEM), and L. ornamentation detail (SEM); Eriotheca pentaphylla in polar view-M. general aspect (SEM); E. pentaphylla in equatorial view-N. aperture (SEM) and O. ornamentation detail (SEM). Arrow in $\mathbf{C}$ indicates endoaperture. 
Table 3. Measurements of apertures and exine layers of pollen grains of species within the subfamily Bombacoideae occurring in areas of restinga (coastal woodland) and Atlantic Forest in the state of Rio de Janeiro ( $\mathrm{n}=10$ grains/species).

\begin{tabular}{|c|c|c|c|c|c|c|c|c|}
\hline \multirow{3}{*}{ Species } & \multicolumn{3}{|c|}{ Colpus } & \multicolumn{2}{|c|}{ Endoaperture } & \multicolumn{3}{|c|}{ Exine layers } \\
\hline & \multicolumn{3}{|c|}{$(\mu \mathrm{m})$} & \multicolumn{2}{|c|}{$(\mu \mathrm{m})$} & \multicolumn{3}{|c|}{$(\mu \mathrm{m})$} \\
\hline & length & width & margin & length & width & exine & sexine & nexine \\
\hline Bombacopsis calophylla & 12.8 & 2.4 & 1.2 & 5.1 & 3.2 & 2.3 & 1.3 & 1.0 \\
\hline B. glabra & 19.5 & 3.5 & 3.6 & 8.6 & 4.5 & 4.7 & 2.8 & 1.9 \\
\hline B. stenopetala & 15.3 & 2.2 & 3.5 & 7.0 & 2.7 & 5.3 & 3.3 & 2.0 \\
\hline Ceiba crispiflora & 14.3 & 2.3 & --- & 6.9 & 3.2 & 4.1 & 3.1 & 1.0 \\
\hline C. erianthos & 19.0 & 2.6 & --- & 6.9 & 3.4 & 3.1 & 2.1 & 1.0 \\
\hline C. speciosa & 14.8 & 2.7 & --- & 6.7 & 3.8 & 5.0 & 3.5 & 1.5 \\
\hline Eriotheca pentaphylla & 10.9 & 2.2 & --- & 5.2 & 7.9 & 3.4 & 2.4 & 1.0 \\
\hline Pachira aquatica & 14.8 & 2.8 & --- & 6.9 & 3.8 & 2.9 & 1.9 & 1.0 \\
\hline Pseudobombax grandiflorum & 24.7 & 8.3 & --- & 9.7 & 8.3 & 2.3 & 1.2 & 1.1 \\
\hline Pseudobombax marginatum & 34.3 & 2.1 & --- & 11.6 & 7.0 & 3.0 & 2.0 & 1.0 \\
\hline Spirotheca rivieri & 14.6 & 2.0 & --- & 5.7 & 3.2 & 4.1 & 2.8 & 1.3 \\
\hline
\end{tabular}

Pollen key for Bombacoideae species

1. Pollen grains without "calotte"

2. 5-colporate pollen grains, pentagonal amb

Ceiba erianthos

2. 3(-4)-colporate pollen grains, subcircular or subtriangular amb

3. Pollen grains with duplicolumellate sexine with one of the rows showing shorter columellae ........ Ceiba speciosa

3. Pollen grains with simplicolumellate sexine

4. Lalongate endoaperture, reticulum with intensely granulate lumina

Eriotheca pentaphylla

4. Lolongate endoaperture, reticulum without intensely granulate lumina. Ceiba crispiflora

1. Pollen grains with "calotte"

5. Rugulate or "vermiculate" sexine

6. Large "calotte" with truncated contours, rugulate sexine in the apocolpium, sinu-aperturate ....Bombacopsis calophylla

6. Small "calotte" with rounded contours, "vermiculate" sexine, planaperturate. Bombacopsis glabra,

5. Reticulate sexine

7. Muri of the reticulum with spinules ("reticulum cristate"). Bombacopsis stenopetala

7. Muri of the reticulum without spinules

8. Muri of the reticulum are high and narrow, with apparent columellae, lumina without ornamentation. Pachira aquatica

8. Muri of the reticulum are low, wide, with no apparent columellae, lumina with ornamentation

9. Muri of the reticulum without minor lumina around major lumina ....................Pseudobombax grandiflorum

9. Muri of the reticulum with minor lumina around major lumina...... Pseudobombax marginatum

\section{Discussion}

Here, we analyzed the pollen grains 11 species within six genera. Most of those species could be separated on the basis of characters related to sexine ornamentation and to the number of apertures (see pollen key). The absence of a "calotte" separated the genera Ceiba and Eriotheca from the four other genera evaluated. Some species are differentiated by particular characters: in Bombacopsis glabra and B. stenopetala, the sexine is rugulate or vermiculate; Ceiba speciosa has an atypical duplicolumellate sexine (one of the rows has columellae starting from the tectum and continuing toward the basal layer); in Pachira aquatica the reticulum has muri with spinules ("reticulum cristate").

Robyns (1963), in his monograph on the genus Bombax sensu lato (Bombacaceae), used palynological attributes associated with the analysis of macromorphological characters to achieve taxonomic delineation among various species of the Bombax complex, including Bombacopsis calophylla, $B$. glabra, B. stenopetala, Eriotheca pentaphylla, Pachira aquatica, Pseudobombax grandiflorum, and P. marginatum. The results obtained here, in general, are very similar to those 

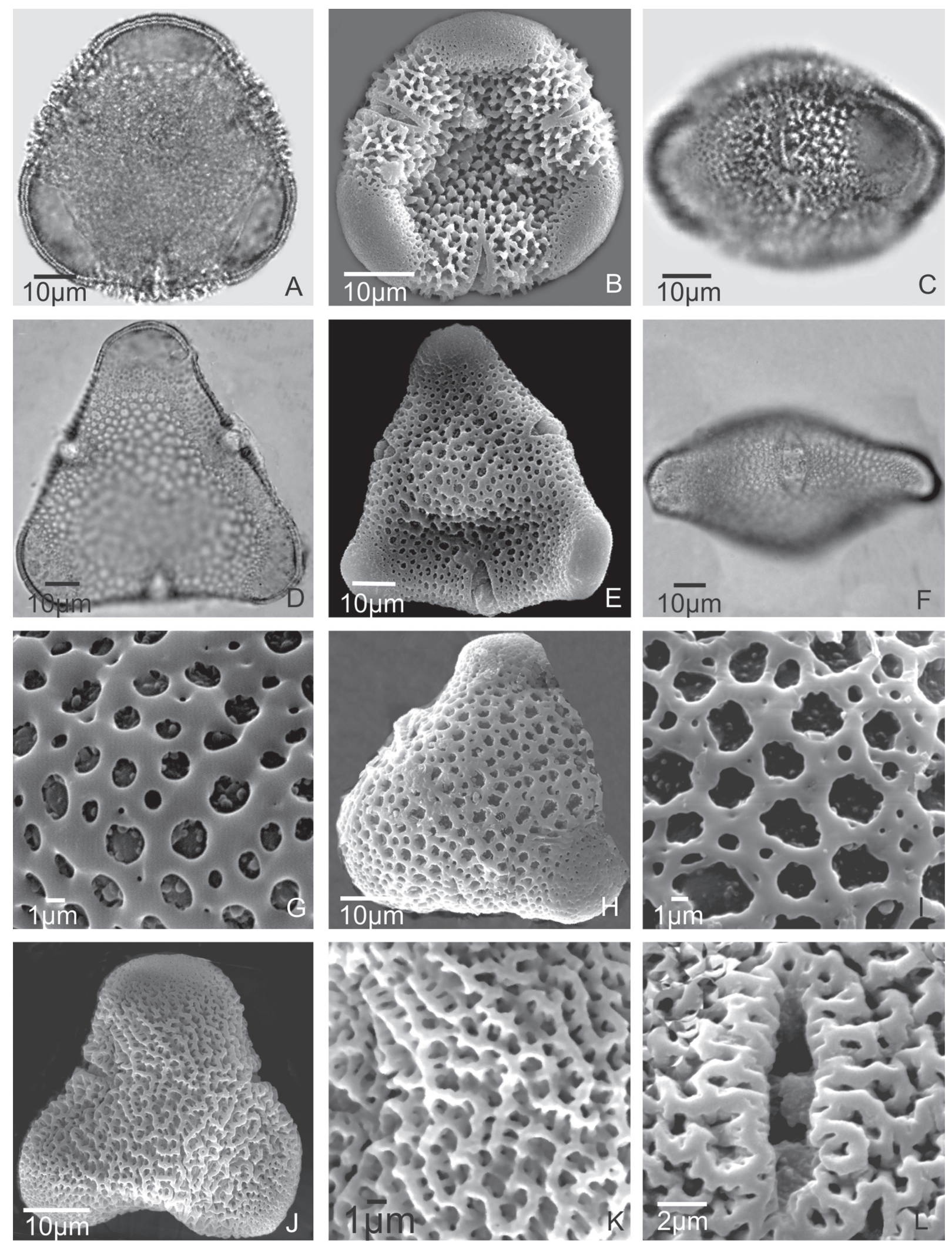

Figure 3. Pollen grains of species within the subfamily Bombacoideae (genera Pachira, Pseudobombax, and Spirotheca) occurring in areas of restinga (coastal woodland) and Atlantic Forest in the state of Rio de Janeiro, under light microscopy (LM) and scanning electron microscopy (SEM): Pachira aquatica in polar view-A. optical section (LM) and B. general aspect (SEM); Pachira aquatica in equatorial view-C. aperture (LM); Pseudobombax grandiflorum in polar view-D. optical section (LM) and E. general aspect (SEM); Pseudobombax grandiflorum in equatorial view-F. aperture (LM) and G. ornamentation detail (SEM); Pseudobombax marginatum in polar view - H. general aspect (SEM) and I. ornamentation detail (SEM); Spirotheca rivieri in polar view-J. general aspect (SEM) and K. ornamentation detail (SEM); S. rivieri in equatorial view-L. aperture detail (SEM). 
obtained by Robyns (1963), who used only light microscopy, the exception being the description of the type of aperture in B. glabra, which that author categorized as colpate whereas we found it to be colporate.

Tsukada (1964) analyzed the pollen grains of 31 taxa subordinated to various genera, including the species Ceiba erianthos, Pachira aquatica and Spirotheca rivieri. In comparing our results with those of that authors, we identified differences regarding the shape of pollen grains and the thickness of the exine in Ceiba erianthos and in Pachira aquatica, as well as regarding the type of aperture in Ceiba erianthos.

Palacios-Chávez (1966) analyzed the pollen grains of trees in the state of Morelos, Mexico. Within the family Bombacaceae (subfamily Bombacoideae), the author examined three species of Ceiba: C. aesculifolia (H.B.K.) Britt. \& Baker; C. parvifolia Rose; C. pentandra (L.) Gaertn.; and Bombax ellipticum H.B.K. Although those were not the same species examined here, we compared our results with those of that author and identified differences. Whereas Palacios-Chávez (1966) reported that all three species were tricolporate with a "per-reticulate" sexine, we found that the Ceiba species evaluated here were (3-4)-5-colporate with a characteristically reticulate sexine.

In a study of pollen grains of savanna species, SalgadoLabouriau (1973) examined several families, including Bombacaceae (species currently subordinated to Bombacoideae), creating or accepting pollen types. Within the type Bombacopsis, the author subordinated the species Bombacopsis amazonica A. Robyns, B. calophylla (K.Schum.) A. Robyns, B. macrocalyx, B. nervosa (Ducke) A. Robyns, B. paraensis (Ducke) A. Robyns, and B. stenopetala (Casar) A. Robyns. This type is characterized especially by oblate or peroblate shapes, by a salient equatorial "calotte", constricted or not constricted at the base, with a planaperturate amb. In comparing our results with those of that author, we found that ours did not allows results with those presented here, does not enable B. calophylla and B. stenopetala to be subordinated to the type Bombacopsis (with a reticulate surface, the tectum has spines or other elevations; the muri is simplicolumellate, duplicolumellate or pluricolumellate). The species analyzed here showed pollen grains with a sexine that is rugulate in the apocolpium and microreticulate to rugulate near the apertures, muri with sparse perforations and psilate, with perforations in the mesocolpium (B. calophylla) or sexine in almost entire "vermiculate" surface with isolated pilate elements, scabrate on the "calotte" (B. glabra and B. stenopetala).

The type Chorisia speciosa is characterized by putting together pollen grains of Chorisia speciosa with large polar area, 4(5)-colporate, very small colpi, lolongate endoaperture, reticulate sexine, high and simplicolumellate muri. In the new classification, Chorisia was synonymized with Ceiba. In this study, we analyzed three Ceiba species, including Ceiba speciosa,. The characters found for Ceiba crispiflora and C. erianthos in the present study are dissimilar to those of the type accepted by Salgado-Labouriau (1973), especially in terms of the number of apertures (here 3- and 5-colporate) and the type of muri (here simplicolumellate). Only C. speciosa has attributes similar to those of the type Chorisia speciosa. The type Eriotheca, created by the same author, comprises seven species of Eriotheca, among them, E. pentaphylla, the pollen grains of which show characters similar to those of the type. To establish the type Pseudobombax, Salgado-Labouriau (1973) analyzed nine taxa of Pseudobombax, two of which (Pseudobombax grandiflorum and $P$. marginatum) were also examined here and can be subordinated to the type on the basis of their pollen characters.

Nilsson \& Robyns (1974) described a new species of Eriotheca (E. obcordata) using specimens collected in Bahia. In their diagnosis, the pollen grains showed the typical characters of the genus and of the Eriotheca species analyzed here (E. pentaphylla).

\section{Conclusion}

On the basis of our findings, the following pollen characters can be considered the most diagnostic of the species evaluated:

- pollen grains with a "calotte", planaperturate, or sinu-aperturate - in Bombacopsis, Pachira and Pseudobombax

-3-colporate pollen grains-in all 11 species

- reticulate sexine-in nearly all of the species

- "vermiculate" sexine-in two of the three species of Bombacopsis (B. glabra and B. stenopetala)

- rugulate sexine-in Bombacopsis calophylla

- sexine microreticulate on the entire surface-in Spirotheca rivieri;

- sexine with difference in the ornamentation between the apocolpium and the mesocolpium-in all of the species, except Ceiba crispiflora, C. erianthos, C. speciosa and Eriotheca pentaphylla.

- Sexine with duplicolumellate muri and with one of the columellae rows being shorter-in Ceiba speciosa.

In the pollen key presented here, most of the species could be separated by palynological attributes, the only exceptions being Bombacopsis glabra and B. stenopetala. Therefore, we believe that the present study can contribute to the taxonomic organization of the subfamily Bombacoideae, and that our data can be useful in future phylogenetic studies.

\section{Acknowledgments}

We are grateful to the staff of the Laboratory of Cell Ultrastructure at the Biophysics Institute of the Universidade 
Federal do Rio de Janeiro (UFRJ, Federal University of Rio de Janeiro), for providing logistical support, and to Noêmia R. Gonçalves, for providing technical assistance with the scanning electron microscopy. This study received financial support from the Brazilian Conselho Nacional de Desenvolvimento Científico e Tecnológico (CNPq, National Council for Scientific and Technological Development; fellowship grants to VHRA and VCE) and from the Fundação de Amparo a Pesquisa do Estado do Rio de Janeiro (FAPERJ, Foundation for the Support of Research in the State of Rio de Janeiro).

\section{References}

Abreu, V.H.R.; Bove, C.P.; Philbrick, C.T.; Mendonça, C.B.F. \& GonçalvesEsteves, V. 2012. Pollen morphology of the aquatic Brazilian endemic genus Castelnavia Tul. \& Wedd. (Podostemaceae). Plant Systematics and Evolution 298: 1455-1461.

Aguiar, A.C.A.; Gonçalves, V.M.; Gonçalves-Esteves, V. \& Yamamoto K. 2008. Palynotaxonomy of Brazilian species of Polygala. Botany Journal Linnean Society 157: 609-619.

APG II. 2003. An update of the Angiosperm Phylogeny Group classification for the orders and families of flowering plants. Botanical Journal of the Linnean Society 141: 399-436.

Bayer, C.; Fay, M.; Bruijn, A.; Savolainen, V.; Morton, C.; Kubitzki, K.; Alverson, W. \& Chase, M. 1999. Support for an expanded family concept of Malvaceae within a recircumscribed order Malvales: a combined analysis of plastid atpb and rbcl DNA sequences. Botanical Journal of the Linnean Society 129: 267-303.

Duarte, M.C. 2006. Diversidade de Bombacaceae Kunth. no Estado de São Paulo. Dissertação de mestrado, São Paulo, Instituto de Botânica da Secretaria de Estado do Meio Ambiente.

Erdtman, G. 1960. The acetolysis method. A revised description. Svensk Botanisk Tidskrift 39: 561-564.

Faegri G., Iversen J. 1966. Textbook of modern pollen analysis. 2 ed. Copenhagen: Scandinavian University Books.

Hesse, M.; Halbritter, H.; Zetter, R.; Weber, M.; Buchner, R.; Frosch-Radivo, A. \& Ulirch, S. 2009. Pollen terminology: an illustrated handbook. Wien, Springer-Verlag.

Melhem, T.S.; Barros, M.A.V.C.; Corrêa, A.M.S.; Makino-Watanbe, H.; Capelato, M.S.F.S. \& Gonçalves-Esteves, V. 2003. Variabilidade Polínica em Plantas de Campos do Jordão (São Paulo, Brasil). Boletim do Instituto de Botânica 16: 16-104.

Moreira F.F., Vaz A.M.S.F., Mendonça C.B.F. \& Goncalves-Esteves V. 2013. The systematic value of pollen morphology in trees and shrubs species of Bauhinia L. (Caesalpinioideae subg. Bauhinia - sect. Pauletia) occurring in Brazil. Acta Botanica Brasilica 27: 400-417.

Nilsson, S. \& Robyns, A. 1974. Pollen morphology and taxonomy of the genus Quararibea s.l. (Bombacaceae). Bulletin du Jardin Botanique National de Belgique 44: 77-99.

Nilsson, S. \& Robyns, A. 1986. Bombacaceae 14. In: Nilsson, S. (Ed.). World pollen and spore flora. Almqvist \& Wiksell, Stockholm.

Palacios-Chávez. 1966. Morfologia de los granos de pólen de árboles Del Estado de Morelos. Anales de la Escuela Nacional de Ciencias Biológicas México 16: 41-169.

Perveen, A., E. Grafstrom And G. El-Ghazaly. 2004. World Pollen and Spore Flora 23. Malvaceae Adams. P.p. Subfamilies: Grewioideae, Tilioideae, Brownlowioideae. Grana 43: 129-155

Perveen, A. \& Qaiser, M. 2007. Pollen Flora of Pakistan-MalvaceaeGrewioideae-LII. Pakistan Journal of Botany 39: 1-10.

Punt, W., Blackmore, S., Nilsson, S. \& Le Thomas, A. 2007. Glossary of pollen and spore terminology. Review of Paleobotany and Palynology 43: 1-81.

Robyns, A. 1963. Essai de Monographie du genre Bombax L. s.l. (Bombacaceae). Bulletin du Jardin Botanique de l'Etat Bruxelles 33: 1-311.

Robyns, A. 1971. On pollen morphology of Bombacaceae. Bulletin du Jardin Botanique National de Belgique 41: 451-456.

Robyns, A. \& Nilsson, S. 1975. Bombacaceae neotropicae novae V. A new species of Eriotheca from Brazil. Bulletin du Jardin Botanique National de Belgique 45: 155-157.

Robyns, A. \& Nilsson, S. 1981. Bombacaceae neotropicae novae IX. A new species of Eriotheca from Colombia. Bulletin du Jardin Botanique National de Belgique 51: 201-204.

Saba, M.D. 2007. Morfologia polínica de Malvaceae: Implicações taxonômicas e filogenéticas. Tese de Doutorado, Feira de Santana, Universidade Estadual de Feira de Santana (UEFS).

Salgado-Labouriau, M.L. 1973. Contribuição à palinologia dos cerrados. Academia Brasileira de Ciências.

Thiers, B. [continuously updated]. Index Herbariorum: a global directory of public herbaria and associated staff. New York Botanical Garden's Virtual Herbarium. Website http://sweetgum.nybg.org/ih/. [accessed on October, 15, 2012]

Tsukada, M. 1964. Pollen morphology and identification III. Modern and fossil tropical pollen with emphasis on Bombacaceae. Pollen et Spores 6: 393-462. 